\title{
Rusmiddelanalyser i urinprøver
}

Rusmiddeltesting i urinprøver er en diagnostisk undersøkelse av om ett eller flere rusmidler er brukt. Prøvene analyseres for å bringe på det rene om rusmidlene og/eller omdanningsprodukter foreligger i organismen. Et positivt resultat betyr altså at bruk har funnet sted, men ikke nødvendigvis at aktivt rusmiddel fremdeles finnes i organismen (det kan være et inaktivt omdannelsesprodukt som påvises). Formålet med en rusmiddeltesting kan være å få bekreftet en klinisk mistanke om nyoppstått rusmisbruk. Andre ganger kan formålet være å fastslå bruk som strider mot avtaler, regler eller lover der konsekvensene av rusmiddelpåvisning kan være sanksjonære. I slike tilfeller stilles det rettstoksikologiske krav til prøvetaking, forsendelse, analyse og fortolkning som er langt mer rigorøse enn i klinisk diagnostiske situasjoner (1).

Det er gode grunne til å ta urinprøver og ikke bare satse på anamnestiske opplysninger. I visse kliniske situasjoner kommer man langt med anamnese (2), andre ganger ikke (3). Selv i anonyme undersøkelser hvor analyseresultatet ikke har noen praktiske konsekvenser, kan det være betydelig underrapportering, særlig for illegale stoffer (4). Behovet for objektiv informasjon om pågående rusmiddelbruk er viktig i for eksempel LAR-behandling, der rusmidler kan potensere de eventuelt negative kognitive virkninger av metadon og buprenorfin (5) og derved redusere rehabiliteringsmulighetene (6). Sett i relasjon til psykoserisikoen knyttet til bruken av hallusinogener, ketamin, fencyklidin, sentralnervøst stimulerende stoffer (7) og ikke minst til høydosebruk av tetrahydrocannabinol (THC) (8), virkestoffet i cannabis, vil kjennskap om rusmiddelbruken hos pasienter med psykose være viktig (9).

Roar Dyrkorn og medarbeidere drøfter i dette nummer av Tidsskriftet i hvilken grad rusmiddelbruk oppdages ved hjelp av det analyserepertoaret noen store laboratorier i Norge bruker til slike formål (10). De fant en liten, men ikke helt ubetydelig risiko for at rusmiddelbruk ikke ble oppdaget ved bruk av et standard analyserepertoar for rusmidler. Dette så de da de reanalyserte et stort antall urinprøver for ytterligere ti stoffer. Denne risikoen for falskt negative resultater på grunn av manglende undersøkelse kan faktisk være enda større enn det som rapporteres i artikkelen, fordi noen laboratorier i utgangspunktet kan ha et enda smalere testrepertoar enn laboratoriet ved St Olavs hospital. Laboratoriene bør ta konsekvensen av dette og hjelpe rekvirerende lege. For eksempel kan de i sine svarbrev angi alle stoffer det er blitt lett etter og hvilke av disse som er funnet.

En artikkel av Andreas Westin i dette nummer av Tidsskriftet viser at påvisning av tetrahydrocannabinol (THC)-omdanningsprodukt $i$ en urinprøve ikke sier noe om tidspunktet for inntak av cannabis (11). Det fremkommer videre at det å dokumentere et eventuelt nytt inntak hos en tidligere bruker kan være en krevende spesialistoppgave for en klinisk farmakolog.

Begge artiklene berører indirekte et annet viktig forhold: Analyser der man benytter immunologiske teknikker og som er raske å gjennomføre, innebærer en betydelig risiko for falskt positive resultater. Slike analyser vil heller ikke gi et spesifikt resultat for stoffer innen en medikament-/rusmiddelgruppe. For eksempel vil man kunne få som svar at et benzodiazepin er påvist, men ikke hvilket. Det er først når prøven analyseres med spesifikke kromato- grafiske teknikker, som gasskromatografi med massespektrometri (GCMS) eller væskekromatografi med tandem massespektrometri (LC/MS/MS), at et komponentspesifikt resultat vil fremkomme. Igjen bør laboratoriet informere rekvirerende lege om hvilken type metode som er benyttet for å fremskaffe resultatet og hvor spesifikk metoden er.

Det er også viktig å være klar over at urinprøver er uegnet til å kartlegge aktuell rusmiddelpåvirkning når det er viktig, for eksempel hos ulykkesskadede med nedsatt bevissthet, pasienter i rehabiliteringssituasjoner og psykotiske pasienter. Dette skyldes at konsentrasjonen av et rusmiddel i urin ikke behøver å reflektere konsentrasjonen i blod. Skal påvirkning der og da utredes, vil man i tillegg til klinisk vurdering kunne ha nytte av rusmiddelkonsentrasjonsbestemmelser i plasma/serum/blod som et uttrykk for konsentrasjon i hjernen.

For den rekvirerende lege er det altså viktig å kjenne laboratoriets rusmiddelanalyserepertoar, analysemetoder og tolkingskapasitet så man ikke risikerer falskt negative, falskt positive, uspesifikke eller feiltolkede resultater. Det siste er kanskje særlig viktig med henblikk på spørsmål om nytt rusmiddelinntak. Dette vil bli enklere dersom laboratoriene presenterer sine resultater på en klar måte og angir om de er tolket av spesialist.

\section{Jørg Mørland \\ jorg.morland@fhi.no}

Jørg Mørland (f. 1941) er divisjonsdirektør ved Nasjonalt folkehelseinstitutt og professor ved Universitetet i Oslo.

\section{Oppgitte interessekonflikter: Ingen}

\section{Litteratur}

1. Kvalitetskrav til rutiner for rusmiddeltesting hvor positivt analysesvar kan danne grunnlag for iverksettelse av alvorlige sanksjoner. Rundskriv IS-14/2002. Oslo: Sosial- og helsedirektoratet, 2002

2. Helseth V, Lykke-Enger T, Aamo TO et al. Rusmiddelscreening av pasienter i alderen 17-40 år innlagt med psykose. Tidsskr Nor Legeforen 2005; 125. $1178-80$.

3. Mordal J, Holm B, Mørland J et al. Recent substance intake among patients admitted to acute psychiatric wards. J Clin Psychopharmcol 2010; 430: 455-9.

4. Gjerde H, Christophersen AS, Moan IS et al. Use of alcohol and drugs by Norwegian employees: a pilot study using questionnaires and analysis of oral fluid J Occupational Med Toxicol 2010; 5: 13.

5. Lintzeris N, Mitchell TB, Bond A et al. Interactions on mixing diazepam with methadone or buprenorphine in maintenance patients. J Clin Psychopharmcol 2006; $26: 274-83$.

6. Teichner G, Horner MD, Roitzsch JC et al. Substance abuse treatment outcomes for cognitivity impaired and intact outpatients. Addict Behav 2002; 27: $751-63$.

7. Curran C, Byrapopa N, McBride A. Stimulant psychosis: systematic review. Br J Psychiatry 2004; 2185: 196-204.

8. D'Souza CD, Sewell RA, Ranganathan M. Cannabis and psychosis/schizophrenia: human studies. Eur Arch Psychiatry Clin Neurosci 2009; 259: 413-31.

9. Mordal J, Holm B, Gossop M et al. Psychoactive substance use among patients admitted to an acute psychiatric ward: laboratory findings and associations with clinical characteristics. Nord J Psychiatry 2010, doi 10, 3109/08039488.2010. 527014

10. Dyrkorn R, Reimers A, Johannessen $L$ et al. Dekker rusmiddeltester i urin de aktuelle misbruksstoffene? Tidsskr Nor Legeforen 2011; 131: 570-2.

11. Westin AA. Cannabis og urinprøver. Tidsskr Nor Legeforen 2011; 131: 577-80. 